\title{
Struktur Vegetasi dan Karakteristik Habitat Peneluran Penyu Hijau (Chelonia mydas) di Kawasan Konservasi Penyu Pangumbahan Sukabumi
}

\author{
Yorianta Sasaerila Hidayat ${ }^{1}$, Dewi Elfidasari ${ }^{2}, \mathrm{M}$ Qeis $\mathrm{TS}^{3}$ \\ 1, 2, 3Program Studi Biologi, Fakultas Sains dan Teknologi, Universitas Al Azhar Indonesia, Jalan \\ Sisingamangaraja, Kompleks Masjid Agung Al Azhar, Kebayoran Baru, Jakarta Selatan 12110
}

Penulis untuk Korespondensi/E-mail: $\underline{\text { d_elfidasari@uai.ac.id }}$

\begin{abstract}
Abstrak - Penurunan populasi penyu hijau yang terjadi secara terus menerus dari tahun ke tahun, menyebabkan penyu termasuk dalam daftar CITES Appendiks I plus zero quota of wild capture for commercial trade saat ini. Oleh karena itu perlu dilakukan upaya konservasi yang baik untuk menjaga kelestarian penyu hijau. Salah satu proses yang penting diketahui bagi kelangsungan sirkulasi hidup penyu adalah proses bertelur. Oleh karena itu perlu diketahui kondisi pantai yang menjadi habitat penyu bertelur. Penelitian ini bertujuan untuk melakukan identifikasi terhadap jenis dan struktur vegetasi, serta karakteristik habitat bertelur penyu hijau di kawasan konservasi penyu pangumbahan sukabumi. Analisa kuantitatif yang dilakukan berupa penghitungan indeks nilai penting vegetasi dan analisa fisik lingkungan sekitar habitat bertelur penyu. Berdasarkan letak sarang telur penyu, ditemukan sebanyak 12 spesies vegetasi yang terdiri dari 4 jenis berupa pohon besar, 3 jenis berupa pohon kecil, 3 jenis berupa perdu, 3 jenis berupa herba, 1 jenis berupa semak. terdapat lebih dari 3 jenis vegetasi yang sangat penting di pangumbahan yaitu Callophyllum inophyllum, Terminalia catappa, Ipoemoea pes-caprae. Karakteristik fisik pantai pangumbahan juga masih mendukung proses bertelur penyu hijau. Pantai Pangumbahan memiliki rata- rata suhu $20{ }^{\circ} \mathrm{C}-30{ }^{\circ} \mathrm{C}$, intensitas cahaya rendah (0) dan kecepatan angin 2,2 knots serta komposisi pasir yang sesuai.
\end{abstract}

\section{Kata Kunci - Habitat Bertelur, Penyu Hijau, Vegetasi, Pantai Pangumbahan, Karakter Fisik}

Abstract - The decline in green turtle populations that occur continuously from year to year, causing turtles to be included in the list of CITES Appendix I plus zero quotes of wild capture for commercial trade today. Therefore it is necessary to do a good conservation efforts to maintain the sustainability of green turtles. Therefore it is necessary to know the condition of the beach that turtles laying habitat. This study aims to identify the type and structure of vegetation, as well as the green turtle nesting habitat characteristics in turtle conservation area Pangumbahan sukabumi. Quantitative analysis is done by calculating the index of vegetation important values and physical analysis of the environment around turtle nesting habitat. Based on the location of turtle egg nest, found 12 species of vegetation consisting of 4 types of large trees, 3 species of small trees, 3 types of shrubs, 3 types of herbs, 1 species of shrubs. There are more than 3 important vegetation types in pangumbahan namely Callophyllum inophyllum, Terminalia catappa, Ipoemoea pes-caprae. Physical characteristics of pangumbahan beach also still support the process of laying green turtle. Pangumbahan Beach has an average temperature of $20^{\circ} \mathrm{C}-30^{\circ} \mathrm{C}$, low light intensity (0) and wind speed of 2.2 knots and suitable sand composition.

Keywords - Habitat lay eggs, Green Turtle, Vegetation, Pangumbahan Beach, Physical Character 


\section{PENDAHULUAN}

$\mathrm{P}$ enyu merupakan hewan reptil berkarapaks yang memiliki umur panjang yang tersebar luas di Samudera Pasisifk, Samudera Atlantik dan Samudera Hindia. Menurut IUCN penurunan populasi penyu secara terus menerus dari tahun ke tahun, menjadikan penyu termasuk dalam daftar CITES Appendiks I plus zero quota of wild capture for commercial trade saat ini [5]. Rusaknya kawasan pantai kawasan penyu meletakkan telur, perburuan telur, pengambilan telur, dan penurunan jumlah telur yang disebabkan predator alami, manusia, dan mikroba menjadi faktor dalam penurunan jumlah populasi penyu.

Dalam rangka menjaga keseimbangan, pemanfaatan dan kelestarian keanekaragaman satwa yang dilindungi termasuk penyu, Indonesia menetapkan kawasan lindung (konservasi) sebagai kawasan yang melindungi biodiversitas dan ekosistem alamnya. Hal ini sesuai dengan keputusan presiden No. 32 Tahun 1990 [6].

Penyu yang akan bertelur biasanya akan memilih lokasi tertentu untuk meletakkan telurnya. Hal ini berkaitan dengan beberapa faktor keamanan telur diantaranya menghindari dari hewan predator pemangsa telur-telur penyu seperti biawak, anjing, babi, rubah, dan semut. Habitat peneluran penyu hijau umumnya memiliki karakteristik tertentu. Sejumlah informasi menjelaskan bahwa penyu akan memilih habitat peneluran berdasarkan tipe pasir, diameter pasir, kemiringan pantai, dan pulau empat penyu tersebut berasal [2].

\section{Tujuan dan Manfaat}

Penelitian ini bertujuan untuk melakukan identifikasi terhadap jenis dan struktur vegetasi, serta karakteristik habitat penyu hijau di kawasan konservasi penyu pangumbahan sukabumi jawa barat.

Penelitian ini akan memberikan hasil berupa data jenis dan struktur vegetasi, serta karakteristik habitat penyu hijau yang dapat dijadikan referensi bagi pemerintah pusat maupun daerah dalam mengambil kebijakan terkait pengelolaan kawasan konservasi penyu Pangumbahan khususnya dan di berbagai kawasan konservasi penyu lainnya di seluruh Indonesia.

\section{METODOLOGI PENELITIAN}

\section{Objek Penelitian}

Objek penelitian ini adalah penyu hijau yang sedang melakukan aktifitas peneluran dan habitat peneluran di kawasan konservasi penyu pangumbahan.

\section{Waktu dan Tempat}

Penelitian ini dilakukan di kawasan pantai pangumbahan yang masuk dalam kawasan konservasi penyu pangumbahan Sukabumi, Jawa Barat. Dengan waktu selama kurang lebih 2 minggu hingga 4 minggu. Lokasi utama dalam melakukan penelitian berada pada daerah habitat bertelur berada mulai dari wilayah stasiun 1 hingga stasiun 6 .

\section{Alat dan Parameter yang Diukur}

Alat dan parameter fisik dan biologi yang diukur, serta metode pengukuran seperti pada tabel 1 meliputi :

Tabel 1. Parameter, metode dan alat yang digunakan pada peneitian

\begin{tabular}{lll}
\hline Parameter & Unit pengukuran & Metode/alat pengukuran \\
\hline Suhu permukaan sarang & ${ }^{\circ} \mathrm{C}$ & Termometer \\
Suhu dasar sarang & ${ }^{\circ} \mathrm{C}$ & Termometer \\
Kelembaban permukaan & $(\%)$ & Higrometer \\
sarang & $(\%)$ & Higrometer \\
Kelembaban dasar sarang & Knot & Hand Anemometer \\
Kecepatan angin & Lux & Lux meter \\
Intensitas cahaya & $(\%)$ & Analisa laboratorium \\
Kandungan pasir, debu \& & liat &
\end{tabular}




\begin{tabular}{lll}
\hline Parameter & Unit pengukuran & Metode/alat pengukuran \\
\hline Kedalaman sarang & Meter/centimeter & Meteran gulungan \\
Diameter sarang & Meter/centimeter & Meteran gulungan \\
Vegetasi hutan pantai & Individu/m² & Meteran gulungan \& identifikasi \\
Panjang lengkung karapas & Meter/centimeter & SCL (Standar Carapase Length) \\
Lebar lengkung karapas & Meter/centimeter & Meteran gulungan \\
Lebar plastron & Meter/centimeter & Meteran gulungan \\
Jumlah telur & Satuan butir & Pencacahan \\
\hline
\end{tabular}

\section{Tahap Penelitian}

\section{Identifikasi struktur vegetasi pantai pada habitat peneluran}

Identifikasi struktur vegetasi habitat peneluran dilakukan pada pagi-siang hari dengan melakukan plotting $(10 \times 10) \mathrm{m}$ sebanyak 3 buah untuk masing-masing stasiun. Dari hasil pengukuran dan identifikasi akan diketahui keanekaragaman, dominansi, dominansi relatif, frekuensi relatif, kerapatan, kerapatan relatif dan indeks nilai penting (INP).

\section{Identifikasi karakteristik habitat peneluran (sarang alami)}

Data diperoleh berdasarkan jumlah penyu yang melakukan aktivitas bertelur pada suatu habitat peneluran selama masa pengamatan di kawasan konservasi Penyu Pangumbahan. Aktivitas bertelur biasanya dilakukan pada malam hari. Data yang dikumpulkan meliputi pengukuran posisi, luas, lebar dan kedalaman sarang alami, karakter biologi penyu yang bertelur (panjang, lebar dan lengkung karapaks; panjang total penyu), serta sifat fisik lingkungan pada saat penyu melakukan aktivitas bertelur di habitat peneluran.

\section{Analisa Data}

Analisa struktur vegetasi pada habitat peneluran menggunakan rumus menurut Mueller, Dombois dan Heinz (1972) dengan menghitung mala dari Kerapatan (K), kerapatan relatif (KR), frekuensi (F), frekuensi relatif (FK), besar tajuk (Bt), dominansi (D), dominansi relative (DR), dan nilai penting (INP).

\section{HASIL DAN PEMBAHASAN}

\section{Struktur Vegetasi}

Dari hasil eksplorasi ploting berdasarkan letak sarang telur penyu, ditemukan sebanyak 12 spesies vegetasi yang berupa pohon, anak pohon, semak, dan herba. Setiap spesies yang ditemukan tergolong dalam 12 famili serta 12 marga/genus. Berdasarkan pengelompokannya terdata terdapat 4 jenis berupa pohon besar, 3 jenis berupa pohon kecil, 3 jenis berupa perdu, 4 jenis berupa herba, 1 jenis berupa semak. Menurut wawancara petugas setempat sebagian besar dari jenis spesies vegetasi yang ditemukan merupakan tanaman liar yang jenisnya masih terbilang murni dan sudah ada sejak dahulu.

Vegetasi pesisir pangumbahan saat ini banyak dipenuhi oleh semak dan belukar disetiap area vegetasi pantainya. Terlihat pada area pasisir pantai vegetasi diawali dengan terdapatnya Jenis populasi dari spesies Ipoemoea pescaprae dan Spinifex littoreus. Terdapat perbedaan struktur vegetasi di antara area pos konservasi, akan tetapi tumbuhan pandan merupakan vegetasi yang paling sering ditemui di setiap area. Selain itu Tumbuhan jukut kiara (Spinifex littoreus) juga menjadi vegetasi herba yang sangat banyak ditemui mulai dari area pos 3 hingga pos 6 , sedangkan kacang dan ketapang menjadi tumbuhan yang banyak ditemui pada area 1. Dari eksplorasi hanya sedikit pohom besar yang ditemukan di sekitar area sarang bertelur penyu. Pada umumnya masih banyak tanaman berbagai jenis dan tipe akan tetapi tidak masuk dalam cakupan daerah sarang bertelur penyu dan hanya dapat ditemukan di dalam hutan pantai bagian dalam. Menurut data hasil Roemantyo terdapat kurang lebih 66 jenis/spesies vegetasi yang ada di area konservasi apabila dilakukan ploting yang 
luasnya 20x20 m dari sarang kearah dalam hutan [10].

Dari data analisis terhadap jenis pohon, semak dan perdu di kawasan konservasi penyu Pangumbahan ditemukan 12 jenis vegetasi yang berbeda dengan pola pengelompokan 4 jenis pohon, 3 jenis perdu, 4 jenis herba, dan 1 jenis semak (tabel 2).

\section{Pohon}

Dari analisa yang didapatkan berdasarkan metode di temukan 4 jenis dari 12 jenis vegetasi yang ditemukan di sekitar sarang bertelur penyu. Pengamatan dilakukan pada ukuran plot sebesar 16×20x20 di sekitar tempat penyu bertelur. Dari data analisa kerapatan, dominansi, dan frekuensi diketahui bahwa semua vegetasi jenis pohon yang ditemukan merupakan vegetasi penting dengan nilai penting lebih dari 19,0\%. Nyamplung (Callophyllum inophyllum) merupakan vegetasi bertipe pohon yang memiliki nilai penting terbesar $(\mathrm{INP}=33,0 \%)$. Nyamplung merupakan tumbuhan berstruktur pohon yang sering ditemui di pesisir pantai berkisar 50 $100 \mathrm{~m}$ dari bibir pantai. Nyamplung memiliki akar tunjang dan bertajuk rimbun dengan tinggi pohon mencapai $25 \mathrm{~m}$ dan diameter batang sebesar $150 \mathrm{~cm}$. Selain banyak tumbuh di pesisir pantai, nyamplung memiliki nilai luas tajuk yang besar dan memiliki potensi yang besar dalam berbagai hal seperti dalam bahan bakar, bahan bangunan, hingga sebagai tempat berlindung oleh sebagian hewan seperti penyu.

Tabel 2. Daftar tumbuhan di pantai Pangumbahan Sukabumi Selatan.

\begin{tabular}{|c|c|c|c|c|c|c|}
\hline \multirow[b]{2}{*}{ Spesies } & \multirow[b]{2}{*}{ Nama Daerah } & \multirow[b]{2}{*}{ Habitus } & \multicolumn{4}{|c|}{$\begin{array}{c}\text { Analisis pohon, anak pohon, herba, semak/perdu } \\
\text { dan semai pada petak pengamatan }\end{array}$} \\
\hline & & & KR & FR & DR & INP \\
\hline Ipoemoea pes-caprae & Katang-katang & Herba & $31,94 \%$ & $11,98 \%$ & $2,89 \%$ & $46,80 \%$ \\
\hline Canavalia maritima & kacang laut & Herba & $20,38 \%$ & $7,64 \%$ & $2,89 \%$ & $46,80 \%$ \\
\hline Callophyllum inophyllum & Nyamplung & Pohon & $3,85 \%$ & $1,45 \%$ & $27,74 \%$ & $33,0 \%$ \\
\hline Pandanus tectorius & Pandan Duri & Pohon & $4,24 \%$ & $1,59 \%$ & $3,09 \%$ & $31,10 \%$ \\
\hline Hibiscus tiliaceus & Waru & Pohon & $1,35 \%$ & $0,51 \%$ & $5,00 \%$ & $6,90 \%$ \\
\hline Terminalia catappa & Ketapang & Pohon & $1.11 \%$ & $0,42 \%$ & $21,96 \%$ & $23,50 \%$ \\
\hline Spinifex littoreus & jukut kiara & Herba & $13,25 \%$ & $4,97 \%$ & $2,10 \%$ & $20,30 \%$ \\
\hline Cyperus padunculatus & teki laut & Herba & $4,58 \%$ & $1,72 \%$ & $2,89 \%$ & $9,20 \%$ \\
\hline Ischaemum muticum & jukut tembaga & Semak/Herba & $16,96 \%$ & $6,36 \%$ & $1,58 \%$ & $24,90 \%$ \\
\hline Callotropis gigantean & Biduri & Perdu & $1,93 \%$ & $0,72 \%$ & $5,00 \%$ & $7,60 \%$ \\
\hline Scaveola taccada & Buah Hati & Perdu & $0,29 \%$ & $0,11 \%$ & $9,53 \%$ & $9,90 \%$ \\
\hline Voacanga foetida & Daun Tanpa Badak & Perdu & $0,14 \%$ & $0,05 \%$ & $2,10 \%$ & $20,30 \%$ \\
\hline
\end{tabular}

Selain itu diketahui secara berurut vegetasi yang memiliki nilai INP tertinggi lainnya yaitu : Ketapang (Terminalia catappa) dengan nilai INP sebesar $23,5 \%$ dan Pandan berduri (Pandanus tectorius) dengan nilai sebesar $21,9 \%$. Selain itu juga ditemukan tumbuhan Waru dengan INP dibawah $19 \%$ yaitu sebesar $6,9 \%$. Akan tetapi terlihat dari nilai frekuensi dan nilai kerapatan terdapat beberapa perbedaan tinggi nilai diantara ke empat vegetasi.

Dalam nilai Frekuensi terlihat pandan duri memiliki nilai yang paling tinggi dibandingkan vegetasi yang lain $(\mathrm{FR}=1,59 \%$ dan $\mathrm{KR}=$ $4.24 \%$ ). Berarti dapat diketahui bahwa pandan laut memiliki penyebaran yang merata dan sangat sering ditemui dari tiap daerah tempat bertelur penyu.

\section{Perdu}

Dari hasil eksplorasi ploting di sekitar area bertelur penyu, didapati 3 jenis vegetasi yang bertipe perdu. Diantaranya berturut- turut yaitu : biduri (INP $=7.6 \%$ ), Daun Tanpa Badak (INP $=2,3 \%)$, dan buah hati $(\mathrm{INP}=9,9 \%)$. Dari ke tiga jenis itu tidak terdapat vegetasi yang memiliki nilai penting relative diatas dari $19 \%$. Dalam hal ini dapat dikatakan 3 vegetasi tersebut tidak memiliki populasi yang penting baik dalam hal penyebaran, dominansi dan kerapatan. Dari tumbuhan ini tumbuh pada area yang terbuka karna sangat memerlukan sinar matahari yang cukup [10]. Biduri (Cyperus padunculatus) merupakan vegetasi yang mungkin memiliki frekuensi yang lebih besar 
dari pada buah hati. Biduri biasanya lebih banyak tumbuh di pesisir pantai berampingan dengan tumbuhan jukut kiara, sedangkan buah hati lebih banyak tumbuh di daerah hutan pantai dan berlindung di balik naungan pohon besar sepertin ketapang dan nyamplung [10].

\section{Herba dan semak}

Analisis terhadap herba dan semak yang dilakukan pada petak pengamatan $16 \times 10 \times 10$ $m$ didapati 4 jenis vegetasi tipe herba dan 1 vegetasi bertipe semak. Kebanyakan vegetasi herba dan semak yang ada di sekitar tempat bertelur penyu merupakan tanaman pioneer, yang sering menjadi gulma pada area pertanian [10]. Vegetasi dari kedua jenis ini sering terlihat menghiasi area terbuka pesisir pantai pangumbahan dengan warna yang hijau pada saat musim penghujan. Vegetasi ini merupakan tumbuhan liar yang merambat dari bibir pantai terbuka, oleh karna itu banyak sekali ditemukan vegetasi jenis ini pada petak analisis yang ada di area terbuka.

Dari vegetasi bertipe herba berturut didapati populasi katang - katang (Ipoemoea pescaprae), jukut kiara (Spinifex littoreus), teki laut (Cyperus padunculatus), dan kacang laut yang merambat di area 1 hingga 5. Dari analisis nilai penting yang dilakukan tumbuhan katang - katang memiliki INP terbesar (INP $=46,8 \%$ ) dibandingkan vegetasi herba lainnya dan vegetasi keseluruhan lainnya. Tumbuhan ini sering sekali dimanfaatkan oleh manusia sebagai bahan ramuan masakan sayur-sayuran serta obat. Selain itu katang-katang juga berfungsi sebagai tempat berlindung hewan kecil berjenis reptil dan serangga, karna memiliki struktur daun yang lebar dan kerapatan populasi yang tinggi. Selain itu katang-katang sangat berguna bagi penyu sebagai tempat untuk melindungi telur. Oleh karna itu katang - katang merupakan vegetasi yang sangat penting yang ada di pesisir pantai pangumbahan bagi kelangsungan hidup penyu. Selain katang - katang, terdapat 2 jenis herba lain yang penting yaitu secara berurut kacang $(\mathrm{INP}=31,1 \%)$ dan jukut kiara (INP $=20,3 \%)$, sedangkan vegetasi teki laut memiliki nilai INP yang rendah (INP $=9,2 \%)$. Jukut tembaga (Ischaemum muticum).

\section{Kondisi fisik area tempat bertelur penyu \\ Dari profil pangumbahan sudah diketahui bahwa terdapat 6 area tempat bertelur penyu yang masing-masing memiliki luas area $400 \mathrm{~m}^{2}$ dengan struktur yang berbeda. Dari analisis data diketahui bahwa rata-rata setiap area pangumbahan memiliki kecepatan angina laut sebesar 2.6 Knots. Menurut informasi wawancara dari petugas setempat Kecepatan angin sebesar merupakan kecepatan angin yang sesuai untuk penyu bertelur, karena apabila angin laut terlalu besar maka susah untuk penyu melakukan penggalian pada pasir pantai. Selain itu tingginya ombak serta kondisi fisik pasir juga sangat terpengaruh oleh angina yang besar, maka kecepatan angina yang sesuai untuk penyu yaitu kecepatan angina yang kecil atau sedang.}

Tabel 3. Data pengukuran fisik pada sarang bertelur penyu.

\begin{tabular}{|c|c|c|c|c|c|c|}
\hline Measure & Area 1 & Area 2 & Area 3 & Area 4 & Area 5 & Area 6 \\
\hline Kecepatan & 2.3 & $2.6 \mathrm{Knot}$ & 2.2 & 2.2 & 2.3 & $2.2 \mathrm{Knot}$ \\
\hline Angin & Knot & & Knot & Knot & Knot & \\
\hline $\begin{array}{l}\text { Intensitas } \\
\text { Cahaya }\end{array}$ & $0 \mathrm{Cd}$ & $0 \mathrm{Cd}$ & $0 \mathrm{Cd}$ & $0 \mathrm{Cd}$ & $0 \mathrm{Cd}$ & $0 \mathrm{Cd}$ \\
\hline $\begin{array}{l}\text { Suhu luar } \\
\text { sarang }\end{array}$ & $24.7^{\circ} \mathrm{C}$ & $20.7^{\circ} \mathrm{C}$ & $25.7^{\circ} \mathrm{C}$ & $26.6^{\circ} \mathrm{C}$ & $26.2^{\circ} \mathrm{C}$ & $27^{\circ} \mathrm{C}$ \\
\hline $\begin{array}{l}\text { Suhu dalam } \\
\text { sarang }\end{array}$ & $26^{\circ} \mathrm{C}$ & $21.4^{\circ} \mathrm{C}$ & $26.4^{\circ} \mathrm{C}$ & $27.1^{\circ} \mathrm{C}$ & $26.9^{\circ} \mathrm{C}$ & $27.3^{\circ} \mathrm{C}$ \\
\hline $\begin{array}{l}\text { Kelembapa luar } \\
\text { sarang }\end{array}$ & $0.3 \mathrm{RH}$ & $0.2 \mathrm{RH}$ & $0.2 \mathrm{RH}$ & $0.3 \mathrm{RH}$ & $0.3 \mathrm{RH}$ & $0.3 \mathrm{RH}$ \\
\hline $\begin{array}{l}\text { Kelembapan } \\
\text { dalam sarang }\end{array}$ & $0.3 \mathrm{RH}$ & $0.2 \mathrm{RH}$ & $0.3 \mathrm{RH}$ & $0.3 \mathrm{RH}$ & $0.3 \mathrm{RH}$ & $0.3 \mathrm{RH}$ \\
\hline
\end{tabular}

Dari pengamatan fisik secara langsung dikatakan pada saat itu angin sedang bertiup sedang dari selatan ke utara. Selain itu sifat fisik dari intensitas cahaya juga mempengaruhi 
penyu untuk bertelur, karena apabila terlalu terang maka penyu enggan untuk menepi kepantai. Dari data yang di dapat dari setiap pos intensitas cahaya tidak memiliki nilai intensitas sama sekali, hal ini dikarenakan kondisi fisik dari area penyu sangat terhindar dari cahaya penerangan (tabel 3). Dari penampakan secara langsung pada saat itu bulan tertutup oleh awan sehingga tidak terdapat cahaya bulan. Semakin tidak ada cahaya maka semakin besar penyu untuk melakukan peneluran. Ini disebabkan karena penyu yang ingin bertelur memiliki insting untuk menghindari area dengan intensitas cahaya yang besar sebagai cara untuk berlindung dari sudut pengawasan predator [9].

Pada malam hari suhu di luar sarang akan memiliki suhu yang lebih rendah dibandingkan di dalam sarang. Permukaan pasir yang terkena radiasi matahari secara langsung menyebabkan suhu permukaan meningkat [9]. Hal ini menyebabkan suatu konduksi, yaitu proses perpindahan kalor dari permukaan pasir (suhu tinggi) ke pasir yang berada di bagian bawahnya (suhu rendah), begitupula sebaliknya. Hal ini sesuai dengan data pengukuran yang dilakukan, bahwa pada malam hari kondisi suhu di luar lebih dingin dari pada di dalam sarang. Hal tersebut juga berpengaruh pada kelembapan akan tetapi hanya saja tak terlihat perbedaan yang sangat nyata dari pengukuran yang terlihat.

\section{Karakteristik Habitat Tempat Bertelur Penyu}

Perairan karang pada pulau-pulau kecil di sekitar laut merupakan wilayah habitat yang di sukai oleh penyu pada umumnya seperti kepulauan seribu atau pun kepulauan karimun jawa. Pantai yang laindai dan luas yang berhadapan dengan laut serta masih memiliki keanekaragam karang dan lahan lamun yang luas, merupakan tempat yang sangat disukai dan sering dijadikan oleh penyu sebagai habitat bertelur [9]. Tantunya pesisir pantai pangumbahan merupakan salah satu tempat yang sesuai dengan kreteria dari wilayah yang disukai oleh penyu. Seperti yang diketahui wilayah pesisir pantai pangumbahan memiliki pantai pasir landai seluas $2.300 \mathrm{~m}$ dan kawasan perairan laut seluas 1.656 ha dengan hamparan padang lamun dan wilayah karang yang luas. Menurut nutija karakteristik habitat lebih berpengaruh terhadap jumlah keberlangsungan penyu bertelur dan survival rating penetasan tukik dibandingkan karaktersitik wilayah pesisir pantai.

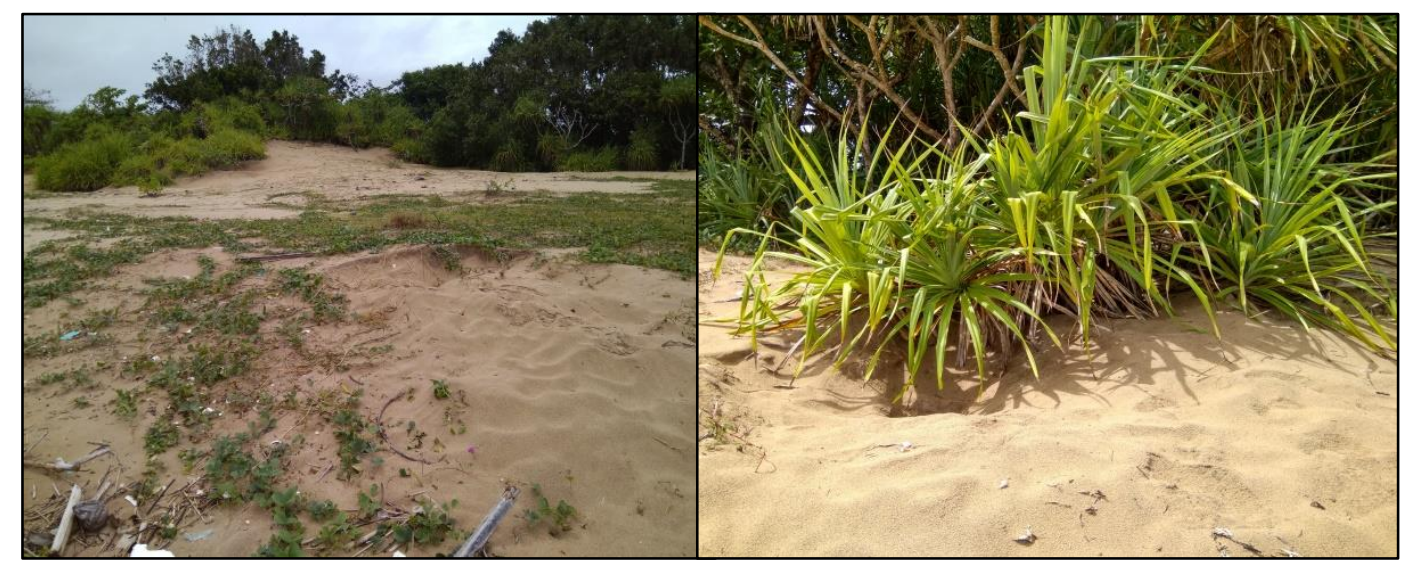

Gambar 3. Foto sarang bertelur penyu pada area pesisir pantai Pangumbahan.

Umumnya karakteristik habitat penyu dengan pantai yang landai dengan kemiringan $\pm 30^{\circ}$ dengan ketinggian ombak $30-80$ meter. Selain itu pangumbahan memiliki 3 wilayah utama yang terdiri dari hutan/ wilayah vegetasi pantai, lading rumput laut yang beragam serta terdapat karang serta koral didasar laut. Wilayah mangrove merupakan ciri karakteristik penyu belimbing, sedangkan Susunan vegetasi pandan duri (Pandanus tectorius), semak belukar dan waru laut merupakan ciri-ciri karakteristik dari habitat bertelur penyu hijau dan jenis penyu lainnya. Tebukti Pada daerah pangumbahan setiap sarang yang ditemukan memiliki keanekaragaman semak serta jumlah populasi pandan yang terdapat di seluruh bagian area pesisir pantai pangumbahan [9].

Selain itu pantai pangumbahan merupakan 
daerah pantai supratidal, penyu pada umunya memilih untuk membuat sarang bertelur pada daerah supratidal atau daerah yang tak terkena pasang. Struktur pasir atau pasir kwarsa merupakan salah satu komponen utama dalam ciri tampak pada sarang bertelur penyu. Sifat karakteristik dari bentuk pasir halus dan kasar menentukan kemudahan penyu dalam menggali sarang. Ukuran pasir yang terlalu besar dan kasar kan menyulitkan penyu untuk menggali, karena semakin besar ukuran permukaan dan kerapatan sekumpulan partikel semakin besar gaya gesek yang ditimbulkan. Maka semakin besar pula gaya usaha yang akan digunakan oleh penyu untuk membuat sarang.

Selain itu suhu pada sarang dan kelembapan atau kadar air dalam pasir dibutuhkan dalam perkembangan embrio. Pasir pantai memiliki daya penyimpanana air sebesar $30 \%-40 \%$, dan daya kadar penyimpanan air yang paling efektif pada pasir untuk perkembangan embrio sebesar $20 \%$ [14]. suhu di dalam dan diluar sarang yang paling efektif dalam adalah antara $24^{\circ} \mathrm{C}$ hingga $33^{\circ} \mathrm{C}$ untuk perkembangan embrio yang baik [15].

\section{KESIMPULAN DAN SARAN}

Dari hasil yang didapat dapat disimpulkan bahwa masih terdapat 7 vegetasi utama yang penting dalam area pesisir pantai pangumbahan yaitu dari spesies Callophyllum inophyllum, Pandanus tectorius, Terminalia catappa, Canavalia maritime, Ipoemoea pes-caprae, Voacanga foetida, Ischaemum muticum, dan Scaveola taccada. Wilayah pantai pangumbahan memiliki kualitas lingkungan yang sesuai bagi kelangsungan proses bertelur penyu dengan rata- rata suhu $20 \mathrm{oC}-30 \mathrm{oC}, 0$ intensitas cahaya dan kecepatan angina 2,2 knots. Pantai pangumbahan memiliki karaktersitik pantai yang landai dengan karaktersitik habitat sarang yang memiliki jarak yang besar dari batas pasang, serta vegetasi yang cukup yang terdiri dari semak dan pohon (pandan duri, nyamplung, dll). Sehingga dapat disimpulkan bahwa pantai pangumbahan sangat berpotensi menjadi tempat untuk sarang telur penyu karna memiliki karakteristik yang dapat mendukung kelangsungan hidup penyu.

Saran dari kesimpulan yang sudah di dapat masih banyak kekurangan yang dilakukan oleh peniliti baik dalam metode penentuan plot ataupun dalam mencari indeks-indeks sesuatu yang penting untuk diukur. selain itu perlu dikaji kembali tentang asal dari muasal vegetasi tersebut dan sebarapa cepat tumbuhan itu untuk tumbuh. agar mengetahui secara jelas bagaimana kaitannya dalam rencana membangkitkan daya suksesi ekologi pesisir pantai pangumbahan lewat jenis vegetasi yang penting. lalu penelitian lanjut tentang keterkaitan antara penyu dan vegetasi juga harus lebih diteliti.

\section{DAFTAR PUSTAKA}

[1] Bustard RH, Sea Turtle : Natural History And Conservation, Collins, Sidney, press Inc. 1972.

[2] Heediawan I, Analisis Habitat Penyu Hijau (Chelonia mydas L) Di Pantai Pangumbahan Kabupaten Sukabumi, Institut Pertanian Bogor, Bogor. 2003.

[3] IUCN. Chelonia mydas.http://www.iucnredlist.org/details /summary/4615/0, 2015. (Diakses Pada April 2016).

[4] Janawi, Perkembangan Suhu Sarang Penetasan Buatan Pada Penetasan Telur Penyu Hijau (Chelonia mydas) Di Pantai Pangumbahan Kabupaten Sukabumi, Universitas Suryakencana, Cianjur. 2009.

[5] Limpus CJ, Marine Turtles Populations Of Southeast Asia And The Western Pasific Ragion : Distributional And Status Proceeding Of The Workshop On Marine Turtles Research And Management In Indonesia., Australia:Wetland International/Phpa/ Environmental. 1996.

[6] Mukminin A, Studi Habitat Peneluran Penyu Hijau (Chelonia mydas L) Di Pulau Sangalaki Kepulauan Derawan Kabupaten Berau, Kalimantan Timur, Institut Pertanian Bogor, Bogor, 2002.

[7] Mueller and D. Dambois, "Natural vegetation and agricultural development in the hill country of Ceylon," The J. of the Wildlife and Nature Protection Society of Ceylon, vol. V, pp. 262-263, 1972.

[8] Nutija I, Biologi Dan Ekologi Pelestarian Penyu, Bogor: Institut Pertanian Bogor. 1992. 
[9] Roemantyo AS \& Wiadnyana NN, Struktur dan komposisi vegetasi sekitar sarang penyu hijau (Chelonia mydas L) Pantai Pangumbahan Sukabumi Selatan Jawa Barat. Berita Biologi. Vol. 11, no. 3, pp 373-387, 2012.

[10] Segara RA, Studi Karakteristik Biofisik Habitat Peneluran Penyu Hijau (Chelonia mydas L) Di Pangumbahan Sukabumi, Jawa Barat, Institut Pertanian Bogor, Bogor, 2008.

[11] Spotila JR, Sea Turtle, A Complete Guide To Their Biology, Behaviour And Conservation, Baltimore: The John Hopkins University, 2004.
[12] Susilowati, Studi parameter biofisik pantai peneluran penyu hijau (Chelonia mydas L) di Pantai Pangumbahan Sukabumi, Jawa Barat. Bogor : Institut Pertanian Bogor, 2002.

[13] Widiastuti, HH, Karakteristik Biofisik Habitat Peneluran Penyu Hijau (Chelonian mydas L) Dan Interaksinya Dengan Populasi Penyu Hijau Yang Bertelur Di Pantai Pangumbahan, Kabupaten Sukabumi, Provinsi Jawa Barat. Skripsi. Fakultas Perikanan Dan Ilmu Kelautan. Institute Pertanian, Bogor, 74p, 1998.

[14] Yusuf A, Mengenal Penyu, Yayasan Alam Lestari Press,Jakarta. 97p, 2000. 